Article

\title{
Dynamics of Aboveground Natural Enemies of Grasshoppers, and Biodiversity after Application of Paranosema locustae in Rangeland
}

\author{
Wang-Peng Shi ${ }^{1,2}, * \mathbb{D}$, Xiao-Yu Wang ${ }^{2}$, Yue Yin ${ }^{2}$, Yu-Xing Zhang ${ }^{2}$, Um-e-Hani Rizvi ${ }^{2}$, \\ Shu-Qian Tan ${ }^{2}$, Chuan Cao ${ }^{2}$, Hong-Yan $\mathrm{Yu}^{3}$ and Rong Ji ${ }^{1, *}$ \\ 1 College of Life Science, International Cooperative Research Centre for Cross-border Pest Management in \\ Central Asia, Xinjiang Normal University, Urumqi 830054, China \\ 2 Department of Entomology, China Agricultural University, Beijing 100193, China \\ 3 Qinghai Rangeland Work Station, Xining 810008, China \\ * Correspondence: wpshi@cau.edu.cn (W.-P.S.); jirongxj@aliyun.com (R.J.)
}

Received: 3 June 2019; Accepted: 19 July 2019; Published: 26 July 2019

check for updates

\begin{abstract}
Substantial harm to ecosystems from the use of chemical pesticides has led to an increasing interest in the use of biopesticides to control grasshoppers in rangelands, including China. One such potential biopesticide for control of grasshoppers is the fungus Paranosema locustae. In this study, the dynamics of aboveground natural enemies of grasshoppers and arthropod diversity 0-9 years after application of P. locustae were investigated in rangeland in Qinghai Plateau, China. We found that the number of species and of individuals of aboveground natural enemies increased by $17-250 \%$ and $40-126 \%$, respectively, after spraying P. locustae, and that the main natural enemies showed three peaks after treatment. The conventional indices of species diversity $\left(\mathrm{H}^{\prime}\right)$ and evenness $\left(\mathrm{J}^{\prime}\right)$ increased by 11-267\% and 13-171\%, respectively, after treatment with $P$. locustae. The results showed the positive effects of $P$. locustae on aboveground natural enemies and biodiversity in an arthropod community in Chinese rangeland. Paranosema locustae is thought to be a safe biological control agent for grasshopper management in Northwestern China.
\end{abstract}

Keywords: Paranosema locustae; biodiversity; grasshoppers; biological control

\section{Introduction}

More than 40 species of pest insects affect some or all of the 400 million hectares of grasslands in China. Of these species, grasshoppers are the most important, causing the largest losses in pastures and crops [1]. In an average year, more than 15-20 million hectares of grassland in northern China experience grasshopper outbreaks, and such outbreaks are common on the Qinghai-Tibet Plateau. These outbreaks have led to the need for continued research on biological control, because of the potential damage to the environment and rangeland ecosystems from the widespread use of chemical pesticides. The need for a biological alternative is especially important for the Qinghai-Tibet Plateau in China.

Lots of entomopathogens have been evaluated for grasshopper control, including Paranosema locustae Canning (Microsporidia: Nosematidae), Metarhizium spp [2], Malamoeba locustae (King et Taylor) [3], and Beauveria bassiana (Balsamo) Vuillemin. Meanwhile, Metarhizium acridum (Driver \& Milner) J.F. Bisch., Rehner \& Humber (Green Muscle ${ }^{\circledR}$, Green Guard ${ }^{\circledR}$ ) is effective in controlling the desert locust and Australian plague locust, Chortoicetes terminifera Walker [4]. More than 120 species of grasshoppers are susceptible to $P$. locustae [5]. The high spore production of P. locustaeinfected hosts, the vertical transmission of the disease through its host, and its wide host range within acridid grasshoppers gives it the potential for wide application for controlling grasshoppers in grasslands. 
Over the past twenty years, more than 1 million hectares have been treated with P. locustae in China, demonstrating the efficacy of this biological agent for managing grasshoppers [6]. P. locustae remains in grasshopper populations even in high ultraviolet rays' area Qinghai Plateau for many years, and the density of primary grasshopper species was kept below EIL in these treated areas [7]. Predatory natural enemies are important vectors for this microsporidian disease [8]. A great deal of attention has been paid to the effects of the pathogen on non-target arthropods, especially on the main natural enemies of grasshoppers and insect biodiversity, in general, in rangeland. The current study examines the effects of P. locustae on the principal groups of aboveground natural enemies of grasshoppers and arthropod biodiversity in a rangeland arthropod community over a nine-year period following application in the Qinghai-Tibet Plateau.

\section{Materials and Methods}

\subsection{Entomopathogen Formulations}

P. locustae from North America was propagated at the China Agricultural University, Beijing, China, by inoculating laboratory-reared third instar Locusta migratoria with spores via oral inoculation in water at $1.0 \times 10^{5}$ spores $/ \mathrm{mL}$. After rearing inoculated grasshoppers for 30-40 days, spores were collected from cadavers, with an average yield of $2.0 \times 10^{10}$ spores per locust. The spores were formulated in water $\left(1.0 \times 10^{10}\right.$ spores/mL water) and stored in a freezer [8]. When most grasshoppers in the field were in the third instar, formulated spores were applied as an ultra-low-volume spray using a Taishan 1806 mobile fogging machine (Taian Pesticide Machine Ltd., Taian, China). The formulated dose level was $7.5 \times 10^{9}$ P. locustae spores in $12 \mathrm{~L}$ water $/ \mathrm{hm}^{2}$.

\subsection{Experimental Plots}

The experimental sites covered an area of 15,000 hectares in Tianjun County (Altitude, $3417 \mathrm{~m}$; $99^{\circ} 02^{\prime} \mathrm{E} ; 37^{\circ} 18^{\prime} \mathrm{N}$ ), Qinghai-Tibet Rangeland. There were three plots for both treated and control; every plot was 1500 hectares of natural pasture; and there were discrete areas separated by untreated terrain.

\subsection{Sampling}

For nine years after treatment with $P$. locustae, grasshoppers and aboveground main natural enemies [9], such as formicid ants, the carabid beetle Aristochroa venusta Tschitschérine, the scelionid wasp Scelio nikolski, the meloid Epicauta gornami Marseul, the sarcophagid fly Sarcophaga filipievi (Rodhain), the bombyliid fly Systoechus sp., spiders, and the agamid lizard Phrynocephalus vlangalii Strauch were collected from the treated and control area at the end of August every year; the initial time of 0 is the finding for the year of $P$. locustae application. The different stage of natural enemies and arthropods above described were collected with an insect suction collector (UNIVAC, Burkard Agronomics, England) at all treated and untreated plots [10], and insect densities were estimated within square aluminium frames (length $\times$ width $\times$ height: $1 \times 1 \times 0.5 \mathrm{~m}$ ), making 50 such collections to estimate insect density within each plot.

All insects were collected from the areas defined by the aluminium frames with suction provided by the D-vacs, and all collected material was placed individually by sample into plastic bags before being stored in a freezer for later identification of insect contents. For common species, including Oedaleus decorus asiaticus Bey-Bienko, Dasyhippus barbipes (F.-W.), Bryodema luctuosum luctuosum Stoll, Angaracris barabensis Pallas, and Myrmeleotettix palpalis Zubovski besides the natural enemies above described, the abundance (number of individuals) was noted and all specimens collected were identified.

\subsection{Statistical Analysis}

The conventional indices of species diversity (Shannon diversity, $\left.\mathrm{H}^{\prime}\right)$ and evenness $\left(\mathrm{J}^{\prime}=\mathrm{H}^{\prime} / \mathrm{ln}\right.$ $\left(\mathrm{S}^{\prime}\right)$ [11] were used to compare the species richness and species diversity of arthropod communities of the Qinghai-Tibet Plateau region in the study area. The indices were calculated using data from a 
series of sample collections made in the study area. The variance of the Shannon index and evenness was calculated as per [12,13].

One-way ANOVAs were used to compare the density and rate of infection in grasshoppers between treated and untreated areas with least-significant difference (LSD) analysis used for multiple comparisons to measure the difference between different treatments. SPSS 17.0 was used for the calculations and analysis.

\section{Results}

\subsection{Population Fluctuations of Grasshopper's Natural Enemies}

The sarcophagid fly $S$. filipievi is one of the main parasitoid of grasshoppers, and three population peaks were observed for this species, in the first $\left(2.35 \pm 0.56\right.$ individuals $\left./ \mathrm{m}^{2}\right)$, fifth $\left(10.90 \pm 1.48 / \mathrm{m}^{2}\right)$, and eighth $\left(3.73 \pm 1.07 / \mathrm{m}^{2}\right)$ year after treatment with $P$. locustae, and the sum of all counts of $S$. filipievi showed significant difference for treatment versus control $(F=17.373, d f=8,18, p<0.05)$, but $S$. nikolski $(F=2.21, d f=8,18, p>0.05)$ and Systoechus $(F=1.454, d f=8,18, p>0.05)$ showed any insignificant differences between treatment and control, respectively (Figure 1).
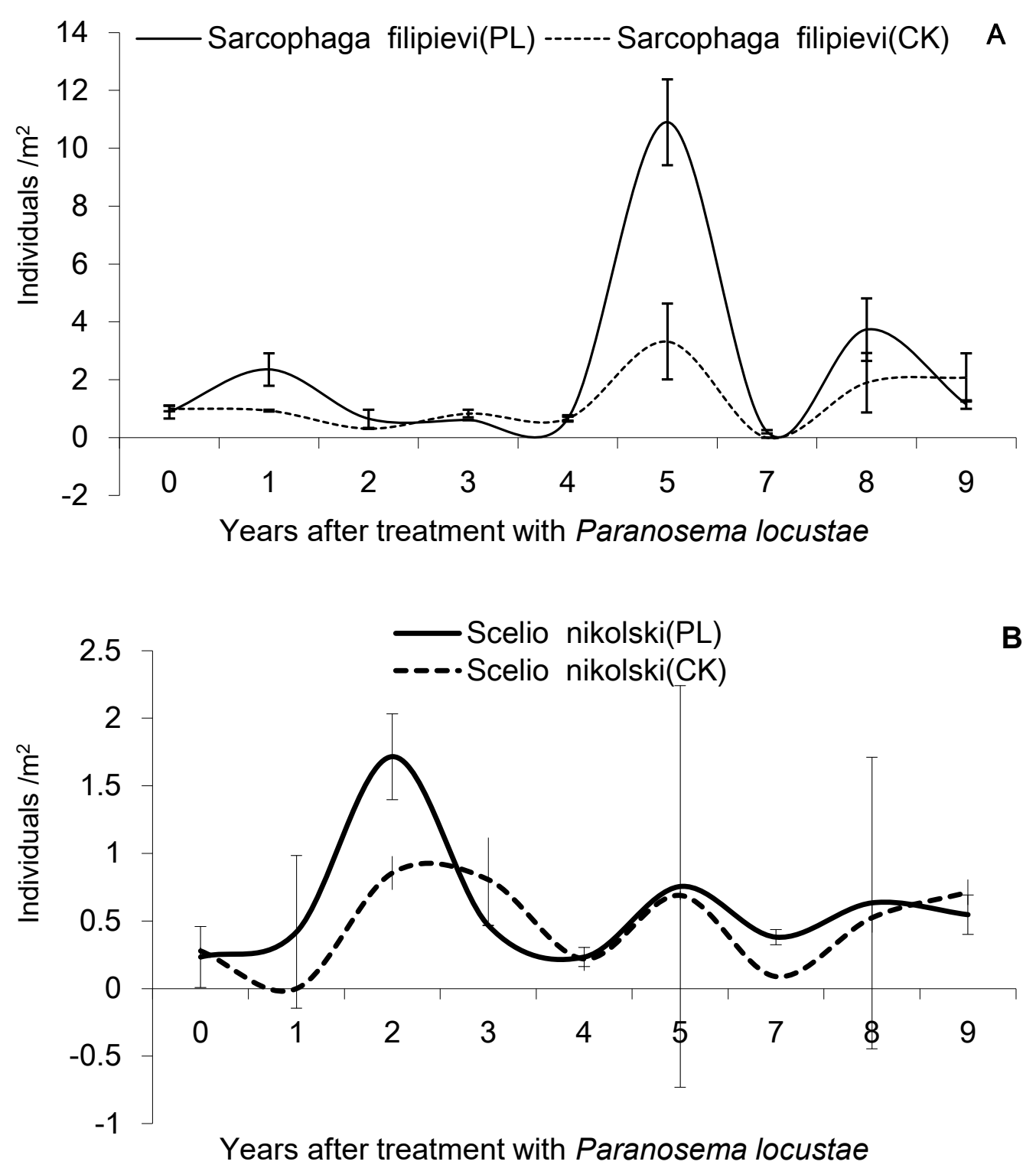

Figure 1. Cont. 


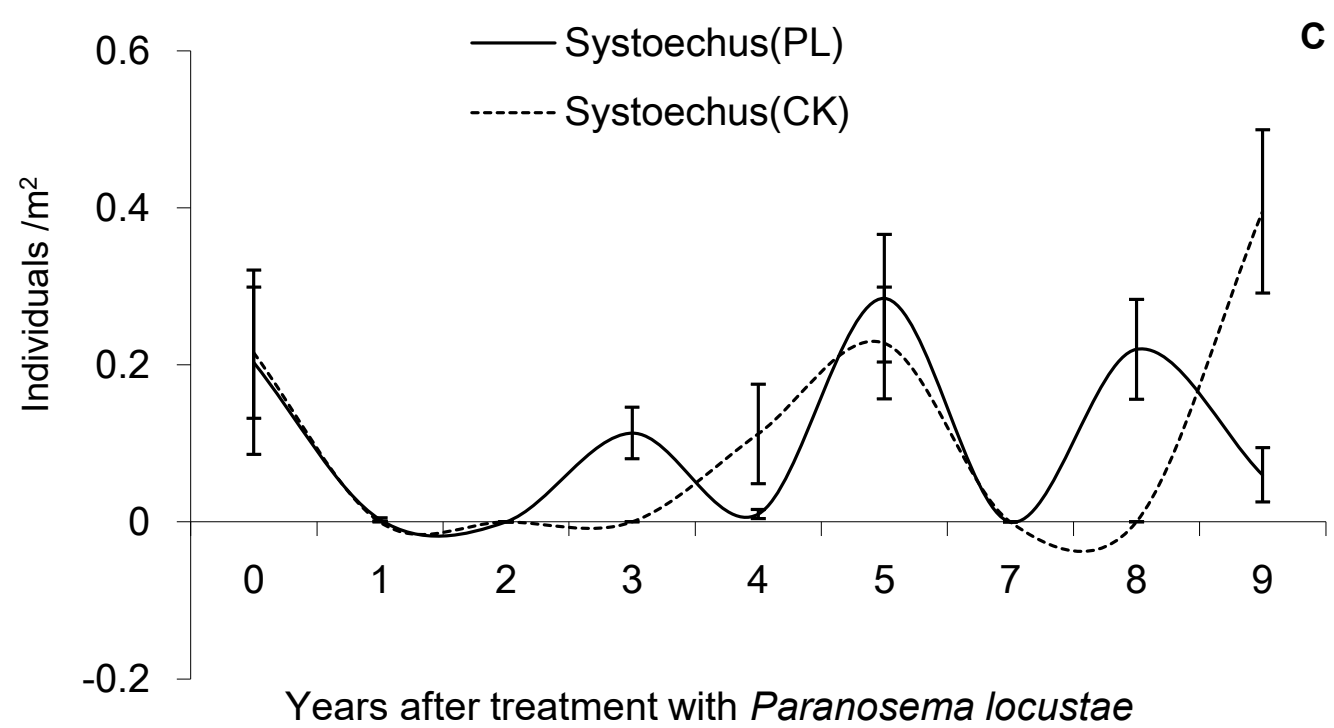

Figure 1. Densities of grasshopper parasitoids in study area, 0-9 years after treatment with Paranosema locustae.

Analysis (one-way ANOVA) of differences of the sum of all counts of parasitoids of grasshoppers between the control (CK) and treated area (PL)—A: S. filipievi $(F=17.373, d f=8,18, p<0.05)$; B: S. nikolski, $(F=2.21, d f=8,18, p>0.05)$; C: Systoechus, $(F=1.454, d f=8,18, p>0.05)$.

A predator, the carabid beetle $A$. venusta, also showed three peaks, in the first $\left(0.55 \pm 0.16 / \mathrm{m}^{2}\right)$, fifth $\left(1.64 \pm 1.03 / \mathrm{m}^{2}\right)$, and ninth $\left(0.53 \pm 0.10 / \mathrm{m}^{2}\right)$ year after treatment. Ants (Formicidae) also showed three peaks, in the third $\left(2.77 \pm 0.31 / \mathrm{m}^{2}\right)$, seventh $\left(3.03 \pm 1.12 / \mathrm{m}^{2}\right)$, and ninth $\left(2.35 \pm 0.61 / \mathrm{m}^{2}\right)$ year after treatment, but the sum of all counts of Formicidae $(F=1.321, d f=8,18, p>0.05)$, A. venusta $(F=0.908$, $d f=8,18, p>0.05)$, E. gornami $(F=1.19, d f=8,18, p>0.05)$, Araneae $(F=2.158, d f=8,18, p>0.05)$, and $P$. vlangalii $(F=0.991, d f=8,18, p>0.05)$ showed no significant difference for treatment versus control, respectively (Figure 2).

Analysis (one-way ANOVA) of differences of the sum of all counts of predators of grasshoppers between the control $(\mathrm{CK})$ and treated area $(\mathrm{PL})-\mathrm{A}$ : Formicidae $(F=1.321, d f=8,18, p>0.05)$; B: Aristochroa venusta $(F=0.908, d f=8,18, p>0.05)$; C: Epicauta gornami $(F=1.19, d f=8,18, p>0.05) ; \mathrm{D}$ : Araneae $(F=2.158, d f=8,18, p>0.05)$; E: Phrynocephalus vlangalii $(F=0.991, d f=8,18, p>0.05)$.

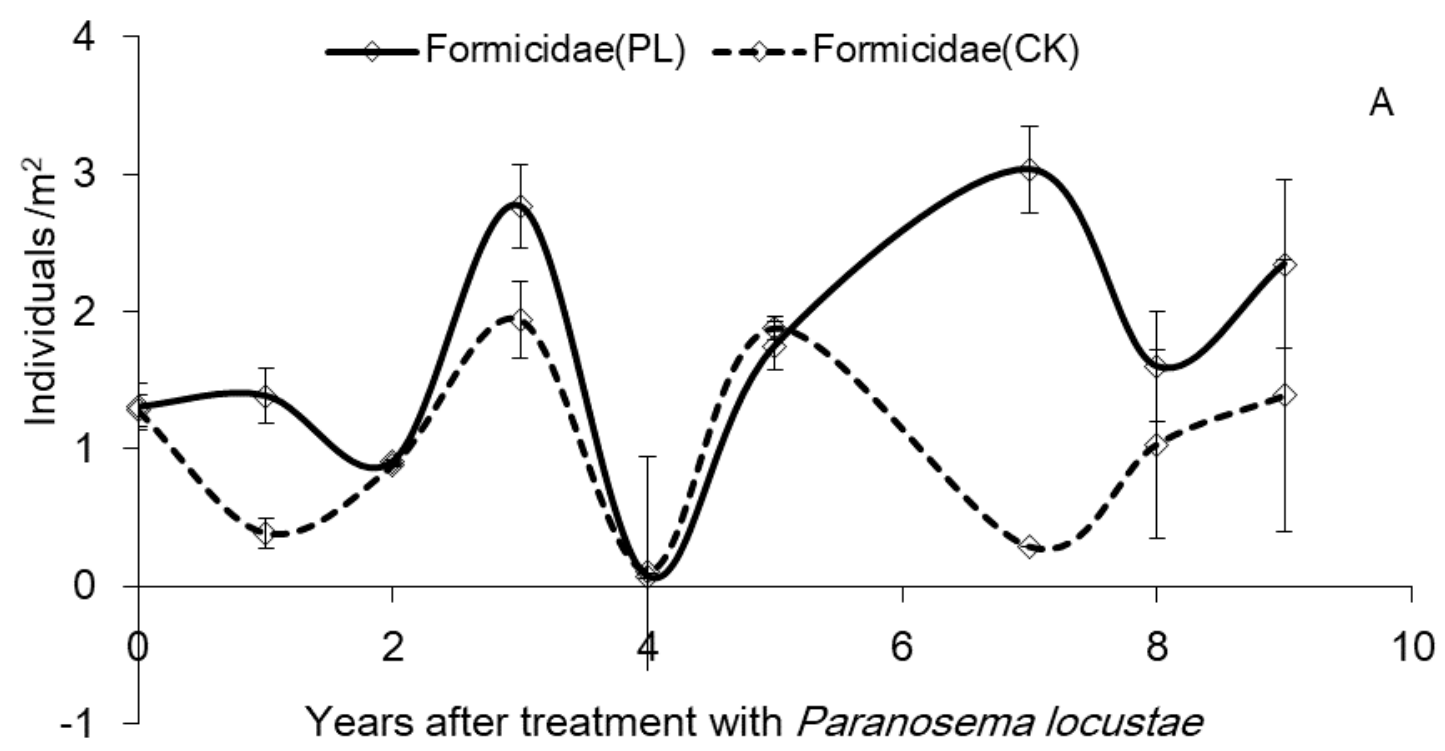

Figure 2. Cont. 

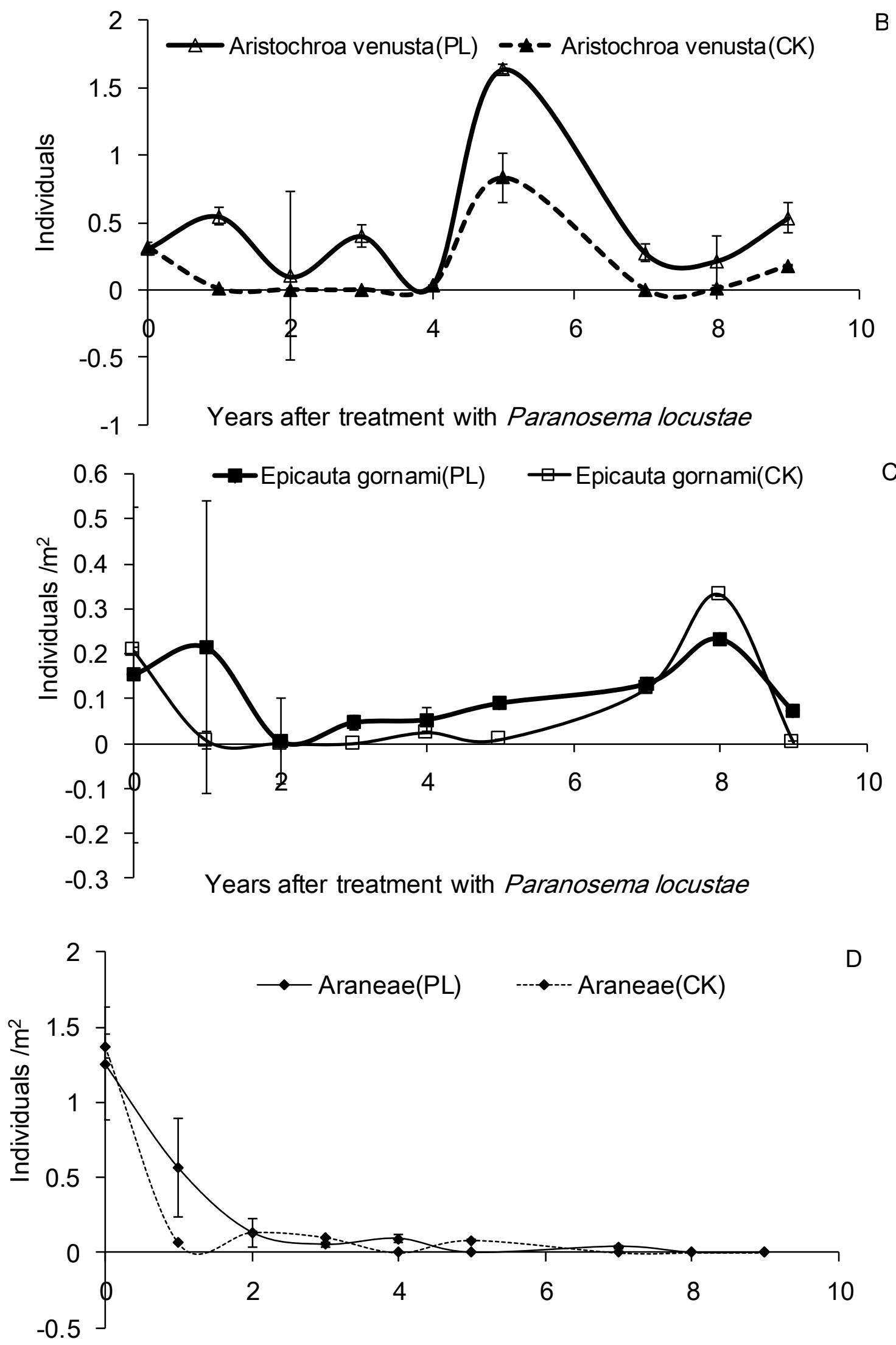

Years after treatment with Paranosema locustae

Figure 2. Cont. 


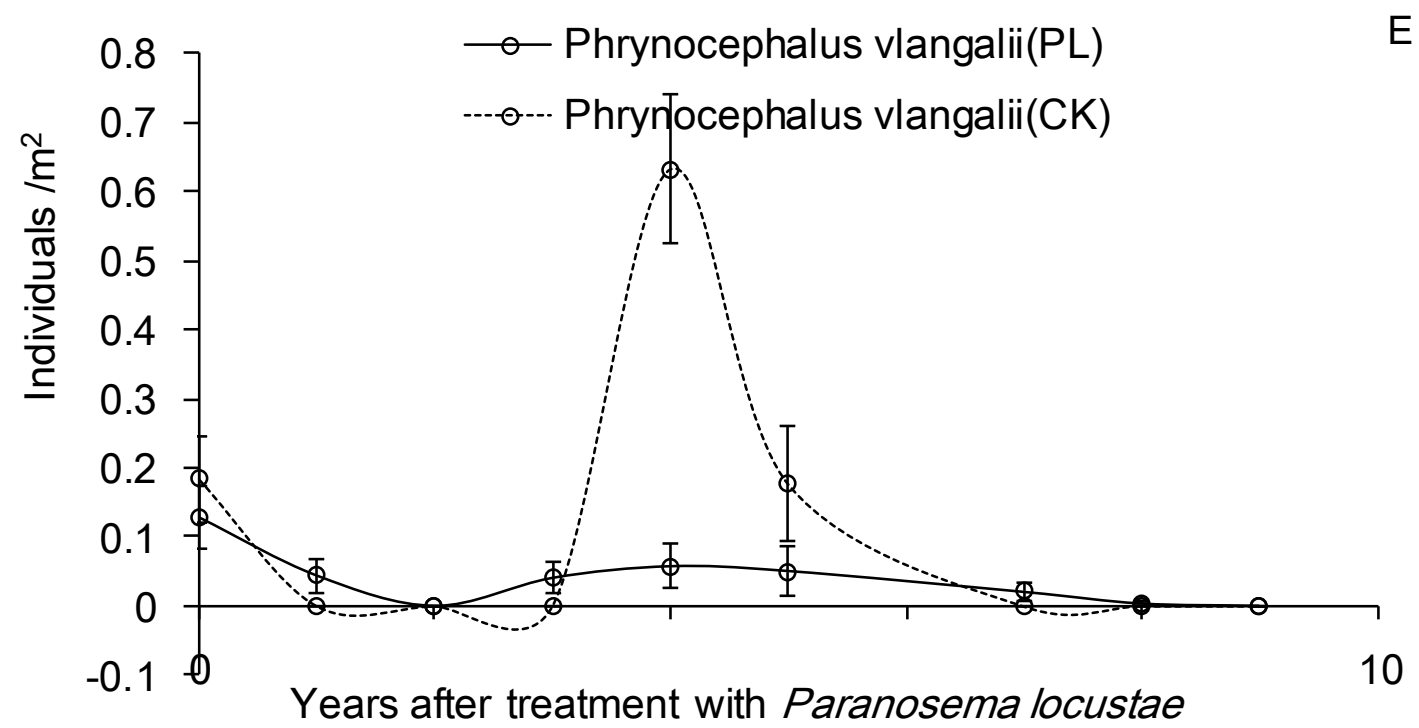

Figure 2. Densities of grasshopper predators 0-9 years after treatment with P. locustae.

\subsection{Diversity of Arthropods after Application of P. locustae}

Nine years after treatment with $P$. locustae, the total number of species and individuals of all the named species collected (see above described) increased by $250 \%$ and $126 \%$, respectively, in areas treated with $P$. locustae. At the same time, the conventional indices of species diversity $\left(\mathrm{H}^{\prime}\right)$ and evenness $\left(\mathrm{J}^{\prime}\right)$ increased by $267 \%$ and $171 \%$, respectively. Analysis of overall data showed that there were significant differences between in the control (CK) and treated area (PL) for both the Shannon index for diversity $\left(\mathrm{H}^{\prime}\right)$ and evenness $\left(\mathrm{J}^{\prime}\right)(F=14.647, d f=9,50, p<0.05)$ and evenness $\left(\mathrm{J}^{\prime}\right)(F=7.354$, $d f=9,50, p<0.05$ ) (Figure 3).

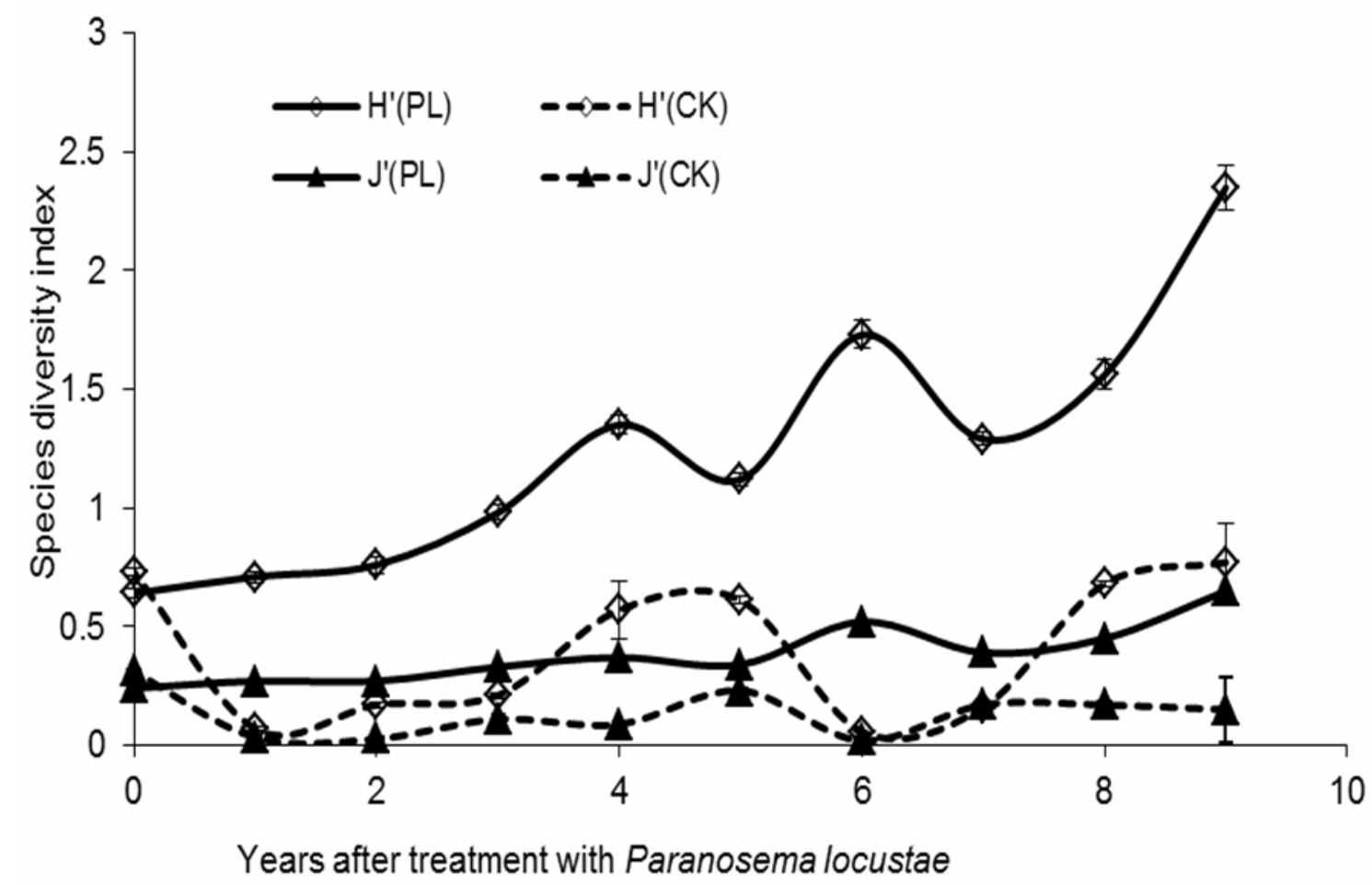

Figure 3. Arthropod richness and evenness indices, 0-9 years after treatment in plots treated with P. locustae. 
Analysis (one-way ANOVA) of overall differences of diversity indices of arthropod between the control (CK) and treated area (PL): the Shannon index for diversity $\left(\mathrm{H}^{\prime}\right)(F=14.647, d f=9,50, p<0.05)$ and evenness $\left(J^{\prime}\right)(F=7.354, d f=9,50, p<0.05)$.

\subsection{Fluctuations of Grasshoppers among Years 0-9 Post-Treatment}

At the time of treatment, grasshoppers were $15.76 \pm 2.67$ individuals $/ \mathrm{m}^{2}$, but it declined by $98.9 \%$ by the fifth year after treatment with P. locustae. Grasshoppers increased after the sixth year and peaked to $13.56 \pm 1.64$ in year nine (Figure 4). Analysis (one-way ANOVA) of differences of the sum of all counts of grasshoppers between the control (CK) and treated area $(\mathrm{PL})(\mathrm{F}=11.221, d f=9,20, p<0.05)$ was done.

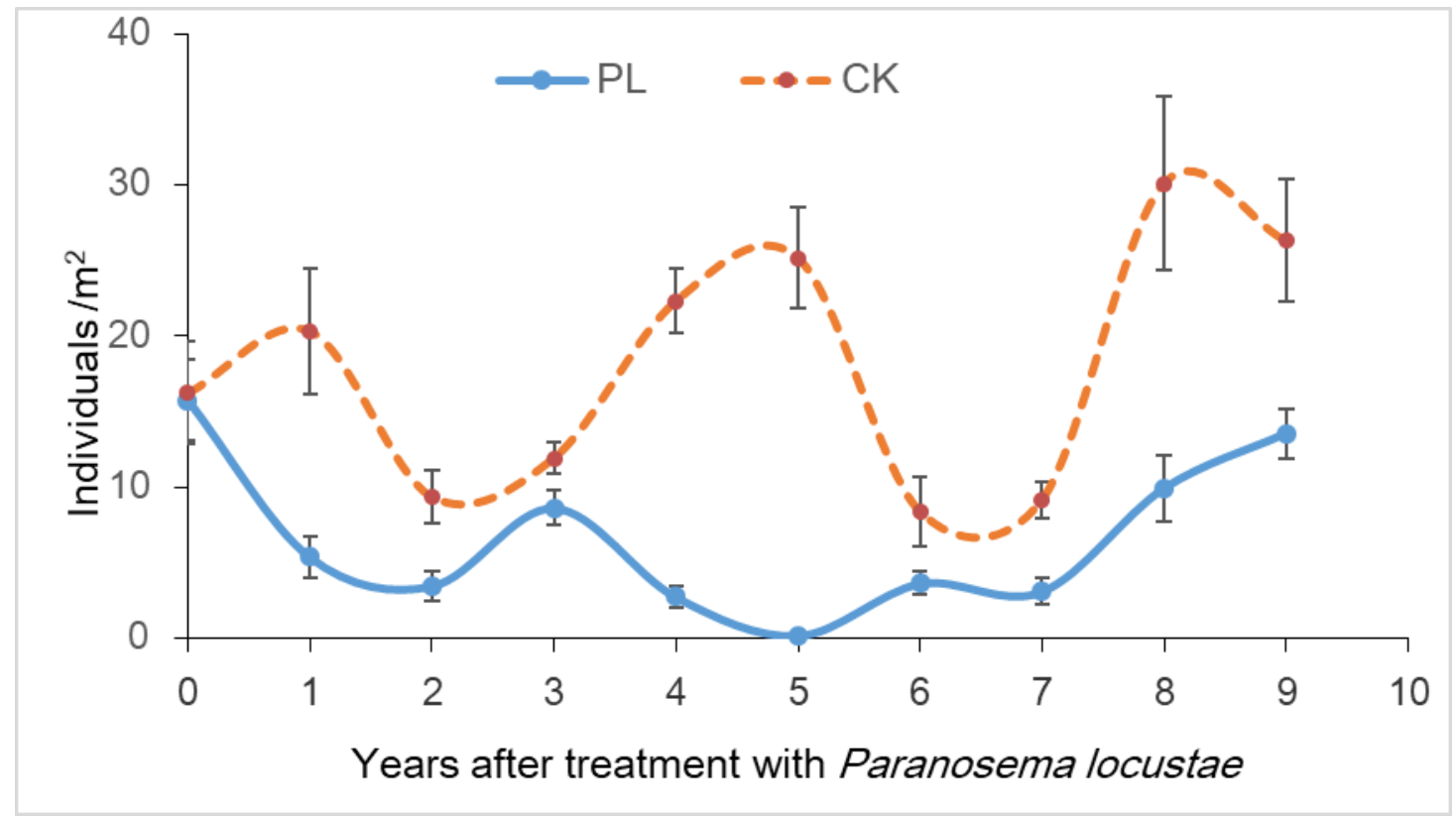

Figure 4. Mean densities $\pm \mathrm{SE}$ (vertical bars) of grasshoppers in the study area, 0-9 years after treatment with P. locustae.

Analysis (one-way ANOVA) of differences of the sum of all counts of grasshoppers between the control $(\mathrm{CK})$ and treated area $(\mathrm{PL})(F=11.221, d f=9,20, p<0.05)$ was performed.

\section{Discussion}

P. locustae has been found to be a useful tool of grasshopper management in the rangeland $[1,6]$. Although P. locustae often causes only low-to-moderate levels of direct mortality post-treatment [14], the cumulative usefulness of $P$. locustae can be far greater [6,15]. In the present study, we found increases in both the number of species and the number of individuals of natural enemies of grasshoppers in the study area over the nine-year period after the application of $P$. locustae, demonstrating an indirect benefit for controlling grasshoppers with this bio-agent.

In addition to the level of grasshopper mortality obtained using products like P. locustae, grasshopper management programs should consider the sustainability of their practices and long-term effects on the health of the rangeland ecosystem [1]. A similar impact of $P$. locustae on a rangeland system was observed in Xinjiang and Inner Mongolia provinces and in Argentina [15,16], but the causes of the long-term effects post-treatment with $P$. locustae require further research.

In plots treated with chemical pesticides in Tianjun, the carabid beetle A. venusta and the lizard P. vlangalii numbers declined by about $70 \%$ and $35 \%$, respectively, one year after treatment, compared to areas treated with $P$. locustae, and the chemically treated plots had to be re-treated with pesticides after 3-4 years [1]. An important concern for the sustainable use of biological pesticides over wide areas is 
their effect on non-target native arthropods, especially natural enemies of the targeted pest. Arthropods are the most diverse group of organisms in ecosystems and include many species with biodiversity or pest control value. Here, we used diversity assessments of the natural enemy assemblages in $P$. locustae-treated areas to evaluate the impact of $P$. locustae on the main natural enemies and diversity in the study region. Although ants are highly diversified and exhibit several alimentary behaviors, most species of ants are to a greater or lesser degree predators or scavengers, and these ants we investigated like to feed on dead, dying, sick or molting grasshoppers in the grassland; so they were considered as a kind of natural enemy of grasshoppers in the experiment. We found that the common grasshopper natural enemies (Ants, A. venusta, S. nikolski, and S. filipievi) in the area were abundant, and that the conventional indices of species diversity $\left(\mathrm{H}^{\prime}\right)$ and evenness $\left(\mathrm{J}^{\prime}\right)$ showed significant increases, suggesting that $P$. locustae can be considered a safe biological agent to non-target arthropods, and its use advocated in grasshopper management. Another one, the infected grasshopper was easy to be predated by its predators because of slow behavior, which is beneficial for natural enemies of grasshoppers. The predatory natural enemies of grasshoppers are important vectors for P. locustae, so the increases of natural enemies of grasshoppers improve the spread of the pathogen in the field. The density of Araneae has suffered a fall over the nine-year period, and we think that the rainfall and humidity declines have been detrimental to spider in recent years. The impact of Paranosema to native entomopathogeny of grasshopper will be researched further in the future.

The sustained control effect of $P$. locustae on grasshoppers was demonstrated here; the increases of natural enemies of grasshoppers perhaps are a potential factor; $P$. locustae has been found persisting in grasshopper populations many years after application in rangeland [16]; and the persistence of the pathogen also is helpful for long-term control of grasshopper, because the common grasshoppers are susceptible to P. locustae collected in the grassland [7].

\section{Conclusion}

The number of species and individuals of aboveground main natural enemies of grasshoppers and biodiversity of arthropods increased in regions treated with P. locustae. Preventive control of grasshoppers with biological pesticides $P$. locustae has been beneficial for keeping biodiversity of rangeland system.

Author Contributions: W.-P.S., X.-Y.W., H.-Y.Y., R.J. and C.C. conceived the study, developed the methodology, and contributed to the writing of the manuscript. X.-Y.W., Y.Y., Y.-X.Z., U.-e.-H.R., and S.-Q.T. conducted experiments and collected the data. W.-P.S. and H.-Y.Y. analyzed the data and conducted statistical analyses. W.-P.S. secured the funding for the research. All authors have read and approved the final article for submission.

Funding: This research was funded by the National Key Program of China (2017YFD0201200), by the National Natural Science Foundation of China (31772221).

Acknowledgments: English editing of this manuscript by Van Driesche Scientific Editing.

Conflicts of Interest: The authors declare no conflict of interest for this publication. The funders had no role in the design of the study; in the collection, analyses, or interpretation of data; in the writing of the manuscript, or in the decision to publish the results.

\section{References}

1. Zhu, E.L. Sustainable management of locust in China. In National Extension Centre of Agricultural Technology; Agriculture Pres: Beijing, China, 1999; pp. 1-37.

2. Zimmermann, G.; Zelasny, B.R.; Kleespies, M.W. Biological control of African locusts by entomopathogenic micoorganisms. In New Trends in Locust Control; Wilps, H., Krall, S., Eds.; Deutsche Gesellschaft für TechnischeZusammenarbeit: Bonn, Germany, 1994; pp. 127-138.

3. Wilps, H.; Nasseh, O. Field tests with botanicals, mycopesticides, and chitin synthesis inhibitors. In New Trends in Locust Control; Wilps, H., Krall, S., Eds.; Deutsche Gesellschaft für TechnischeZusammenarbeit: Bonn, Germany, 1994; pp. 51-79. 
4. Lomer, C.J.; Bateman, R.P.; Johnson, D.L.; Langewald, J.; Thomas, M. Biological control of locusts and grasshoppers. Ann. Rev. Entomol. 2001, 46, 667-702. [CrossRef] [PubMed]

5. Lange, C.E. The host and geographical range of the grasshopper pathogen Paranosema (Nosema) locustae revisited. J. Orthoptera Res. 2005, 14, 137-141. [CrossRef]

6. Zhang, Z.H.; Yan, Y.H.; Zhang, Z.R.; Zheng, S.Y.; Xiang, S.Y.; Li, F.; Li, Y.S. The protection effect and significance on grassland ecosystem biodiversity of using Nosema locustae to control locusts. Pratacultural Sci. 2003, 9, 17-23.

7. Zhang, K.Q.; Xing, X.J.; Hou, X.M.; Tan, S.Q.; Chen, H.X.; Liu, P.P.; Shi, W.P. Population dynamics and infection prevalence of grasshopper (Orthoptera: Acrididae) after application of Paranosema locustae (Microsporidia). Egypt. J. Biol. Pest Control. 2015, 25, 33-38.

8. Shi, W.P.; Zheng, X.; Jia, W.T.; Li, A.M.; Camara, I.; Chen, H.X.; Tan, S.Q.; Liu, Y.Q.; Ji, R. Horizontal transmission of Paranosema locustae (Microsporidia) in grasshopper populations via predatory natural enemies. Pest Manag. Sci. 2018, 74, 2589-2593.

9. Ren, C.; Jing, X.; Shi, W. Effect of Nosema locustae for controlling grasshopper on natural enemy in the grassland. Heilongjiang J. Anim. Sci. Vet. Med. 2004, 2, 11-13.

10. Shi, W.P.; Chen, X.; Lu, F.; Guo, C. Persistence of Paranosema (Nosema) locustae (Microsporidia: Nosematidae) among grasshopper (Orthoptera: Acrididae) populations in the Inner Mongolia Rangeland, China. Biocontrol 2009, 54, 77-84. [CrossRef]

11. Pielou, E.C. The measurement of diversity in different types of biological collections. J. Theor. Biol. 1966, 13, 131-144. [CrossRef]

12. Pielou, E.C. Shannon's formula as a measure of specific diversity: Its use and misuse. Am. Natur. 1966, 100, 463-465. [CrossRef]

13. Hurlbert, S.H. The nonconcept of species diversity: A critique and alternative parameters. Ecology 1971, 52, 577-586. [CrossRef] [PubMed]

14. Lockwood, J.A.; Bomar, C.R.; Ewen, A.B. The history of biological control with Nosema locustae: Lessons for locust management. Entomol. Exp. Appl. 1999, 19, 333-350. [CrossRef]

15. Shi, W.P.; Peter, G.N.N. The disruption of aggregation behaviour of Oriental Migratory Locusts (Locusta migratoria manilensis) infected with Nosema locustae. J. Appl. Entomol. 2004, 128, 414-418. [CrossRef]

16. Lange, C.E.; Azzaro, F.G. New case of long-term persistence of Paranosema locustae (Microsporidia) in melanopline grasshoppers (Orthoptera: Acrididae: Melanoplinae) of Argentina. J. Inverteb. Pathol. 2008, 99, 357-359. [CrossRef] [PubMed] 